\title{
REVIEW
}

\section{The human pegivirus: A new name for an "ancient" virus. Can transfusion medicine come up with something new?}

\author{
G. MARANO ${ }^{1}$, M. FRANCHINI ${ }^{1,2}$, B. FARINA ${ }^{1}$, V. PICCININI ${ }^{1}$, S. PUPELLA ${ }^{1}$, S. VAGLIO ${ }^{1,3}$, G. GRAZZINI ${ }^{1}$, \\ G. M. LIUMBRUNO ${ }^{1}$
}

${ }^{1}$ Italian National Blood Centre, National Institute of Health, Rome, Italy; ${ }^{2}$ Department of Haematology and Transfusion Medicine, "Carlo Poma" Hospital, Mantua, Italy; ${ }^{3}$ Department of Clinical and Molecular Medicine, "Sapienza" University of Rome, Rome, Italy

Received December 12, 2016; revised March 20, 2017; accepted September 26, 2017

\begin{abstract}
Summary. - Human pegivirus (HPgV, formerly called GB virus C/hepatitis G virus) is a poorly understood RNA virus of the Flaviviridae family. The HPgV infection is common worldwide and the virus is likely transmitted by blood products. At this time, no causal association between HPgV and human diseases has been identified. While waiting for new findings to better understand the Pegivirus genus, the aim of our narrative review is to discuss the currently available information on $\mathrm{HPgV}$ focusing on its prevalence in blood donors and its potential threat to transfusion safety.
\end{abstract}

Keywords: GB virus type C; hepatitis G virus; human pegivirus; Flaviviridae; hepatitis; blood transfusion

\section{Contents:}

1. Introduction

2. Search methods

3. The virus

4. Clinical relevance of $\mathrm{HPgV}$ infection

5. Prevalence and distribution of $\mathrm{HPgV}$

6. HPgV in blood donors

7. Discussion

8. Conclusions

\section{Introduction}

In 2013, the International Committee on Taxonomy of Viruses (ICTV) ratified the creation of a new genus in the family Flaviviridae, the Pegivirus genus (Stapleton et al.,

E-mail: g81.marano@iss.it; phone: +39-3295620931.

Abbreviations: $\mathrm{HPgV} / \mathrm{HGV} / \mathrm{GBV}-\mathrm{C}=$ human pegivirus; $\mathrm{HGV}=$ hepatitis $\mathrm{G}$ virus; $\mathrm{HCV}=$ hepatitis $\mathrm{C}$ virus; $\mathrm{PBMCs}=$ peripheral blood mononuclear cells; ALT $=$ alanine aminotransferase
2011). In the 1960s, in the progression of isolating and identifying the etiologic agent(s) responsible for non-A, non-B hepatitis, a transmission of viral hepatitis from humans to non-human primates (Saguinus labiatus) was achieved by Deinhardt and colleagues (Deinhardt et al., 1967) starting from the serum from a subject with acute hepatitis (whose initials were G.B.). In 1995, the GB virus A and B (GBV-A, GBV-B), two viruses closely related to hepatitis $C$ virus (HCV), were identified, but up to now they have not been found in humans (Schaluder et al., 1995). A third virus was identified and named GBV-C using degenerate oligonucleotides to amplify related viral sequences in human serum samples (Simons et al., 1995). Concomitantly, another research group identified novel RNA virus sequences in the serum of humans with hepatitis, and called this virus hepatitis G virus (HGV) (Linnen et al., 1996). Following analysis of the genome sequences of $\mathrm{HGV}$ and GBV-C revealed that they were minor variants of the same virus species, while GBV-A and GBV-B were distinct (Stapleton et al., 2011). Pegivirus A has been designated as the type species of this new genus and it has been found in primate host species (humans, chimpanzees and several New World 
monkey species) unlike the pegivirus $B$ which was found only in fruit bats (Epstein et al., 2010). On the other hand, $\mathrm{HGV} / \mathrm{GBV}-\mathrm{C}$, currently called human pegivirus ( $\mathrm{HPgV})$, is commonly detected in healthy blood donors at the time of donation, however it has limited pathogenicity and it is not clearly associated with any human disease (Bhattarai and Stapleton, 2012; Chivero et al., 2014). Recently, two independent reports described the discovery of a novel human pegivirus that has been temporarily designated as human hepegivirus 1 (HHpgV-1) (Kapoor et al., 2015) or as human pegivirus 2 (HPgV-2) (Berg et al., 2015). Available data suggest that it is a highly divergent, blood borne virus, and seems to exhibit a low prevalence of viraemia in populations with parenteral exposure risk (Kapoor et al., 2015; Berg et al., 2015).

The aim of this narrative review article is to discuss the currently available information on this virus focusing on its potential threat to transfusion safety.

\section{Search methods}

We analysed the medical literature for published randomized controlled trials (RCTs), observational studies, and reviews concerning the prevalence of $\mathrm{HPgV}$ in blood donors. The PubMed/Medline electronic database was searched without temporal limits using the English and French language as a restriction. The Medical Subject Heading and key words used were: "human pegivirus", "hepatitis G virus", "blood donors", and "blood transfusion". We also screened the reference lists of the most relevant articles for additional studies not selected in our initial literature search.

\section{The virus}

In the last years, several novel pegiviruses have been found in a wide range of mammalian hosts, including bats, primates, rodents, dogs, cows and horses (Thézé et al., 2015). These new discoveries have radically changed our knowledge of the various pegiviruses and their vast range of hosts. The potential for the different species of animal hosts to act as reservoirs of viral infection and sources of crossspecies transmission is well known (Thézé et al., 2015); it has been estimated that they are responsible for a quarter of all recently-emerged human pathogens (Woolhouse et al., 2012).

The HPgV (formerly called GB virus C/hepatitis $\mathrm{G}$ virus) is an enveloped, spherical virus about $50 \mathrm{~nm}$ in diameter. The $\mathrm{HPgV}$ genome is represented by a single-chain RNA ( 9.4 $\mathrm{kb}$ ) with positive polarity. It is similar to the HCV RNA in its organization, i.e. the structural genes are located at the genomic 5 ' region (containing an internal ribosomal entry site (IRES) directing translation of a polyprotein of approxi- mately 3,000 amino acids) and non-structural genes at the 3' end (Thézé et al., 2015). Phylogenetic data, compiled from various parts of the world, revealed the presence of seven distinct HPgV genotypes (Thézé et al., 2015). The virus is efficiently transmitted by parenteral route (sexually, vertically from mother to child, intra-familiarly, intravenous drug use, and through exposure to infected blood and blood components) (Chivero and Stapleton, 2015). Sexual transmission appears to be more efficient than for HCV, probably due to lymphotropism and higher serum virus concentrations (Stapleton et al., 2011).

The E-protein is an important molecule of $\mathrm{HPgV}$ (involved in the virus adhesion and fusion with the host cells) and it is the target for the production of the anti-HPgV antibodies. The viral proteins are not usually detected during active infection, but antibodies against the envelope glycoprotein E2 appear following viral clearance and appear to provide partial protection against reinfection (Chivero and Stapleton, 2015). Therefore, antibodies to $\mathrm{E} 2$ represent a marker of prior infection, although antibody levels may decrease and become undetectable over time (Chivero and Stapleton, 2015; Grassi et al., 2000). Unlike HCV infection, simultaneous detection of viral RNA and antibodies to E2 or other viral proteins is not common (Bhattarai and Stapleton, 2012).

Diagnosis of $\mathrm{HPgV}$ is usually performed through the reverse transcription PCR (RT-PCR) and ELISA. The two above-mentioned diagnostic assays are based on the detection of different viral markers in biological samples: RT-PCR detects HPgV RNA molecules in the patient samples and ELISA detects antibodies to E2-proteins (Schaluder et al., 1995; Chivero and Stapleton, 2015). At the moment, no licensed blood donor screening tests for $\mathrm{HPgV}$ exist.

\section{Clinical relevance of $\mathrm{HPgV}$ infection}

Since its discovery, the primary site(s) of replication and cellular receptors for $\mathrm{HPgV}$ has (have) not been identified and a correlation with non-A/non-E hepatitis remains a controversial issue even though $\mathrm{HPgV}$ RNA has been detected more frequently in patients with acute and chronic non-A/non-E hepatitis than in healthy subjects. Early studies indicated that the virus was hepatotropic (Grassi et al., 2000; Hollingsworth et al., 1998; Guilera et al., 1998), although numerous studies carried out since the late 1990s, have shown that $\mathrm{HPgV}$ is not hepatotropic or only barely detectable in the liver of infected individuals (Pessoa et al., 1998; Chivero et al., 2014). The virus can persist for at least one month in culture in peripheral blood mononuclear cells (PBMCs) from infected individuals (Thézé et al., 2015; Chivero and Stapleton, 2015). Moreover, in serum-derived from infected individuals, $\mathrm{HPgV}$ is capable of infecting PBMCs in vitro (Thézé et al., 2015; Chivero and Stapleton, 
2015). Several lines of evidence failed to identify an association between infection and acute or chronic hepatitis and suggested that it was characterized by marked lymphotropism (Chivero et al., 2014). Earlier studies resulted in the detection of $\mathrm{HPgV}$ RNA in patients with non-A/non-E fulminant hepatitis, and consequently $\mathrm{HPgV}$ was implicated as its causative agent (Yoshiba et al., 1994; Heringlake et al., 1996; Saiz et al., 1997; Sheng et al., 1998; Anastassopoulou et al., 2002). On the other hand, several other studies do not support the hypothesis that $\mathrm{HPgV}$ is capable of inducing fulminant hepatitis and suggest that the HPgV infection is coincidental and transmitted through transfusion of blood or blood products during the illness (Kanda et al., 1996; Haydon et al., 1997; Kapoor et al., 2000; Kumar et al., 2007). To date, HPgV has not been convincingly shown to cause any human disease (Kapoor et al., 2015; Chivero and Stapleton, 2015). No clinical evidence of a liver disease potentially linked to $\mathrm{HPgV}$ infection was observed during a long follow-up of different categories of patients (Lefrère et al., 1997). Linked to its capacity of replication in both $\mathrm{T}$ (CD4+ and CD8+) and B lymphocytes (Kapoor et al., 2015) rather than in hepatocytes (Pessoa et al., 1998), an association between $\mathrm{HPgV}$ viraemia and an increased risk of non-Hodgkin's lymphoma has been suggested (Chivero and Stapleton, 2015). Moreover, several studies have suggested a correlation of $\mathrm{HPgV}$ with other chronic diseases (e.g. aplastic anaemia, chronic renal failure) (Stapleton et al., 2014; Chivero and Stapleton, 2015), but some of them were limited in sample size or were based on small numbers and most of them lacked controls. Interestingly, a beneficial effect of $\mathrm{HPgV}$ infection in human immunodeficiency virus (HIV) disease has been suggested and most studies and a meta-analysis found prolonged survival in HIV-infected individuals co-infected with $\mathrm{HPgV}$ compared with those without $\mathrm{HPgV}$ viraemia (Stapleton et al., 2014). A study by Vahidnia and colleagues (Vahidnia et al., 2012) on transfusion-related $\mathrm{HPgV}$ infection in HIV-infected individuals, confirmed a survival benefit in those subjects who acquire $\mathrm{HPgV}$ through blood transfusion. $\mathrm{HPgV}$ infection seems to have a protective role in $\mathrm{HIV}$-infected individuals reducing immune activation and probably contributing to the detected improvement in HIV clinical outcomes (Chivero et al., 2014; Schwarze-Zander et al., 2012; Lanteri et al., 2015). These findings are probably related to elective $\mathrm{HPgV}$ infection of naive T-cells that subsequently differentiate into effector or memory cells, or alternatively the infection of T-cells regardless of their differentiation state. Moreover, $\mathrm{HPgV}$ RNA was detected in T- and B-lymphocytes, NKcells, and monocytes; it was present in all 14 study subjects' PBMCs, and in populations of T- and B-lymphocytes (Chivero et al., 2014). In 2015, co-infection with HPgV in patients with Ebola virus disease appeared to be associated with improved survival (Lauck et al., 2015).

\section{Prevalence and distribution of $\mathrm{HPgV}$}

Worldwide, approximately 750 million people are actively infected (viraemic) and an estimated 0.75 to 1.5 billion people have evidence of prior $\mathrm{HPgV}$ infection (Chivero and Stapleton, 2015), but there is a large variation and difference in the spread of $\mathrm{HPgV}$ infection in different geographical regions. Actually, in the last three decades, many studies have examined the presence of $\mathrm{HPgV} / \mathrm{HGV} / \mathrm{GBV}-\mathrm{C}$ in several countries, but most of them dealt with $\mathrm{HPgV}$ in adults or in selected groups of subjects or small communities in a vast territory. Generally, high $\mathrm{HPgV}$ prevalence is observed among subjects with the risk of parenteral exposures including those exposed to blood and blood products, those on haemodialysis, those with a history of intravenous drug use, and in subjects with chronic hepatitis C or HIV infection (Bhattarai and Stapleton, 2012). Taking into account the large variability reported in the evaluation of $\mathrm{HPgV}$ in the general population, further research could be justified to evaluate the real burden of the $\mathrm{HPgV}$ infection that, at the moment, appears significantly underestimated.

\section{6. $\mathrm{HPgV}$ in blood donors}

In the past, several studies from different countries investigated the molecular and/or serological HPgV prevalence in blood donor populations alone or compared with other selected clusters of subjects (e.g. healthy people, intravenous drug users, patients on haemodialysis, medical or surgical patients, subjects with chronic hepatitis or chronic diseases, etc.).

The article by Mohr and Stapleton in 2009 (Mohr and Stapleton, 2009) reported the $\mathrm{HPgV} / \mathrm{GBV}-\mathrm{C}$ prevalence rates in blood donors from various regions of the world. The prevalence among blood donors at the time of donation was summarised from the studies available at that time (50 studies, for a total of 11,391 blood donors). The authors stated that infection is common worldwide and is able to persist for decades. Although $\mathrm{HPgV}$ is not as efficient at establishing persistent infection as $\mathrm{HCV}$, an estimated $25 \%$ of infections persist and in the other $75 \%$ viraemia clears within 2 years following infection in the majority of individuals infected by blood transfusion (Chivero and Stapleton, 2015). Moreover, the HPgV-RNA prevalence was higher in blood donors from developing countries $(5 \%-18.9 \%$ in developing countries and $0.5 \%-5 \%$ in developed countries) (Mohr and Stapleton, 2009). In a study carried out among healthy voluntary blood donors in the Indian Armed Forces, Praharaj and colleagues showed that 13 out of 500 subjects (2.6\%) tested where positive for HGV RNA (Praharaj et al., 2005).

Based on the findings from the 71 selected studies published between 1996 and 2015 reported in Table 1, HPgV 
showed seroprevalence of 1\% (Ramezani et al., 2008) to $31.9 \%$ (Sathar et al., 1999) in healthy individuals and blood donors; this rate increases to $34 \%$ in $\mathrm{HCV}$-infected deferred blood donors (Shev et al., 1998). On the other hand, the viral RNA presence of $\mathrm{HPgV}$ ranges from between 0\% (Arankalle et al., 2001; Desai et al., 2004; Kalkan et al., 2005; Barusruk et al., 2006; Ramezani et al., 2008; Deshpande et al., 2013) and $46.7 \%$ (Kar et al., 2000) in healthy blood donors.

Following a more detailed analysis of $\mathrm{HPgV}$ seroprevalence reported in Table 1 for each continent and country, we noted that the serologic assay positivity ranges from $4.9 \%$ (Mastouri et al., 2005) to 31.9\% (Sathar et al., 1999) and the molecular assay positivity ranges from 5\% (Omar et al., 2006) to $18.9 \%$ (Sathar et al., 1999) in Africa; in the Americas, no data about seroprevalence is available (with the exception of the $7.3 \%$ reported in a Canadian study on identity unlinked and short-term deferred donors (Giulivi et al., 2000)) and the molecular assay positivity ranges from 1.5\% (Linnen et al., 1996) to 10\% (Lampe et al., 1998); in Asia, the seroprevalence ranges from 1\% (Ramezani et al., 2008) to $11 \%$ (Xiao et al., 2014) and the molecular assay positivity ranges from 0\% (Arankalle et al., 2001; Desai et al., 2004; Kalkan et al., 2005; Barusruk et al., 2006; Ramezani et al., 2008; Deshpande et al., 2013) to 46.7\% (Kar et al., 2000); in European countries, the seroprevalence ranges from 9.5\% (Mercier et al., 1999) to $24.2 \%$ (Brojer et al., 1999) and the molecular assay positivity ranges from 1\% (Minton et al., 1998 ) to $10 \%$ (Anastassopoulou et al., 2000); the $10.8 \%$ (Moaven et al., 1996) of seroprevalence rate was reported in healthy Australian blood donors and the molecular assay positivity ranges from $2.6 \%$ (Hyland et al., 1998) to $4 \%$ (Moaven et al., 1996) in the same population.

All in all, the data reported in Table 1 confirm the sharp contrast between different geographic areas (non-developed countries (endemic areas) vs. developed countries (non-endemic areas)). However, for most countries only one study on the prevalence of $\mathrm{HPgV}$ in blood donors was available. Furthermore, even when more than one study was carried out in the same country, they were concentrated in a limited period of time (usually in the late 1990s). For the above mentioned reason and for a general lack of data, it is very difficult to evaluate an infection rate trend in blood donors in the same country, except in a very few cases. A stable viral circulation was suggested in Polish (Brojer et al., 1999; Grabarczyk et al., 2006) and Taiwanese blood donors (Wang et al., 1998; Yang et al., 2006), while five studies showed an apparent decrease in the RNA positivity rate from 4\% (Jain et al., 1999; Kar et al., 2000) to 0\% (Arankalle et al., 2001; Desai et al., 2004; Deshpande et al., 2013) over a period of 15 years in voluntary Indian blood donors. Strangely, a 5.8\% HPgV seroprevalence reported in the Spanish general population in 2007 (López-Izquierdo et al., 2007) is nearly three times less than that reported in a more selected population of blood donors in 1997 (Tacke et al., 1997).

When both serologic and molecular assays have been performed, the antibodies to E2-proteins have been found more frequently than viral RNA among healthy blood donors; nevertheless, similar $\mathrm{HPgV}$ prevalence rates detected by serologic and molecular assay ( $4.9 \%$ vs. $5.3 \%$, respectively) have been reported in the study performed by Mastouri and colleagues (Mastouri et al., 2005) with no positive donors for both viral markers and an overall $\mathrm{HPgV}$ prevalence in Tunisian donors more than $10 \%$.

In order to evaluate a relationship between $\mathrm{HPgV}$ infection and alanine aminotransferase (ALT) and/or aspartate aminotransferase (AST) activity in HGV RNA-positive donors compared to a control group of healthy donors, several studies were performed in the late 1990s. Previous studies had shown a higher $\mathrm{HPgV}$ prevalence rate in blood donors with elevated ALT levels in comparison to those with normal ALT (Moaven et al., 1996; Björkman et al., 1998), but these differences were not statistically significant. Moreover, more recent findings suggest that there was no significant difference in the activity of liver enzymes in $\mathrm{HGV} / \mathrm{HPgV}$ RNA-positive donors compared to a control group of healthy donors (Hitzler et al., 2004; Xiao et al., 2014). Similar findings were found in patients with documented post-transfusion $\mathrm{HPgV}$-related hepatitis in whom the plasma ALT peak and the peak viral titers may be discordant, suggesting that $\mathrm{HPgV}$ may not be responsible for the rise in ALT levels (Uygun et al., 2000; Lyra et al., 2005; Stapleton et al., 2014), especially in individuals without risk factors for acquiring parenterally transmitted agents (Feucht et al., 1997). Therefore, increased ALT/AST levels are not to be considered valid surrogate markers for the presence of $\mathrm{HPgV}$.

In our analysis, a certain degree of difference emerges from the comparison between non-remunerated and remunerated blood donors in terms of $\mathrm{HPgV}$ infection rate suggesting that it may be lower among voluntary blood donors. In fact, $\mathrm{HPgV}$-RNA was detected from 0\% (Arankalle et al., 2001; Desai et al., 2004; Kalkan et al., 2005; Barusruk et al., 2006; Ramezani et al., 2008; Deshpande et al., 2013) to $24.6 \%$ (Odeh et al., 2010) in voluntary non-remunerated donors and from $4.3 \%$ (Ren et al., 1998) to $46.7 \%$ (Kar et al., 2000) in paid blood donors (Table 1).

Our study confirms the distribution of $\mathrm{HPgV}$ worldwide and its not negligible presence in healthy individuals like blood donors. Therefore, some limitations should be considered: i) some studies have a small sample size of enrolled blood donors; ii) different serological or molecular assays were used; iii) variability in the demographic and clinical features of the population, differences in host susceptibility or virulence of different viral strains; iv) finally, most of the studies were performed in the 1990s and describe 
Table 1. Prevalence of hepatitis G virus (HGV)/GB virus type C (GBV-C)/human pegivirus (HPgV) in different geographical areas (from 1996 to 2015)

\begin{tabular}{|c|c|c|c|c|}
\hline \multirow[b]{2}{*}{ Continent } & \multirow[b]{2}{*}{ Country } & \multicolumn{2}{|c|}{ Prevalence } & \multirow[b]{2}{*}{ References } \\
\hline & & $\begin{array}{c}\text { Serologic assay } \\
(\%)\end{array}$ & $\begin{array}{c}\text { Molecular assay } \\
(\%)\end{array}$ & \\
\hline \multirow{8}{*}{ AFRICA } & Burkina Faso & N.A. & 7.4 & Tao et al., 2013 \\
\hline & $\begin{array}{l}\text { Democratic } \\
\text { Republic of the } \\
\text { Congo }\end{array}$ & N.A. & 12.7 & Iles et al., 2013 \\
\hline & \multirow{3}{*}{ Egypt } & $\begin{array}{c}23.1 \\
\text { asymptomatic persons }\end{array}$ & N.A. & Darwish et al., 1998 \\
\hline & & N.A. & 5 & Omar et al., 2006 \\
\hline & & N.A. & 12.2 & El-Zayadi et al., 1999 \\
\hline & \multirow{2}{*}{ South Africa } & 31.9 & 18.9 & Sathar et al., 1999 \\
\hline & & N.A. & 11.1 & Casteling et al., 1998 \\
\hline & Tunisia & 4.9 & 5.3 & Mastouri et al., 2005 \\
\hline \multirow{9}{*}{ THE AMERICAS } & \multirow{5}{*}{ Brazil } & N.A. & 9.7 & Levi et al., 2003 \\
\hline & & N.A. & 9 & Bassit et al., 1998 \\
\hline & & N.A. & 7.1 & Oliveira et al., 2002 \\
\hline & & N.A. & 10 & Lampe et al., 1998 \\
\hline & & N.A. & 8.6 & Goubau et al., 1999 \\
\hline & Canada & $\begin{array}{c}7.3 \\
\text { [identity unlinked (IU) and } \\
\text { shortterm temporarily deferred } \\
\text { (STTD)] }\end{array}$ & $\begin{array}{c}1.1 \\
\text { [identity unlinked (IU) and } \\
\text { short-term temporarily } \\
\text { deferred (STTD)] }\end{array}$ & Giulivi et al., 2000 \\
\hline & & N.A. & 2 & Lara et al., 1998 \\
\hline & Honduras & & $\begin{array}{l}\text { healthy Honduran } \\
\text { university students }\end{array}$ & \\
\hline & USA & N.A. & 1.5 & Linnen et al., 1996 \\
\hline \multirow{19}{*}{ ASIA } & Bangladesh & N.A. & 2.2 & Showkath et al., 2014 \\
\hline & \multirow{5}{*}{ China } & N.A & 2.57 & Li et al., 2002 \\
\hline & & N.A. & 15.8 & Yan et al., 2001 \\
\hline & & N.A. & 2 & Wu et al., 1997 \\
\hline & & N.A. & $\begin{array}{c}4.3 \\
\text { paid donors }\end{array}$ & Ren et al., 1998 \\
\hline & & $\begin{array}{c}\operatorname{IgG} 11 \\
\operatorname{IgM} 10.6\end{array}$ & 0.13 & Xiao et al., 2014 \\
\hline & \multirow{6}{*}{ India } & N.A. & 0 & Desai et al., 2004 \\
\hline & & N.A. & 0 & Deshpande et al., 2013 \\
\hline & & N.A. & 4 & Jain et al., 1999 \\
\hline & & N.A. & 16.3 & Arankalle et al., 2001 \\
\hline & & & $\begin{array}{c}\text { paid plasma donors } \\
0 \\
\text { voluntary blood donors }\end{array}$ & \\
\hline & & N.A. & $\begin{array}{c}46.7 \\
\text { commercial blood donors } \\
4.0 \\
\text { voluntary donors } \\
\end{array}$ & Kar et al., 2000 \\
\hline & \multirow{3}{*}{ Iran } & 1 & 0 & Ramezani et al., 2008 \\
\hline & & N.A. & 1 & Amini et al., 2005 \\
\hline & & 8.6 & N.A. & Rezvan et al., 2007 \\
\hline & \multirow{4}{*}{ Japan } & N.A. & $\begin{array}{c}7.4 \\
\text { blood donors with anti- } \\
\text { HCV and HCV RNA }\end{array}$ & Yoshikawa, 1997 \\
\hline & & N.A. & $\begin{array}{c}1.2 \\
\text { healthy volunteers }\end{array}$ & Noguchi et al., 1997 \\
\hline & & N.A. & 0.5 & Orito et al., 1996 \\
\hline & & 2.5 & 1.3 & Saitoh et al., 2002 \\
\hline
\end{tabular}


Table 1 (continued)

\begin{tabular}{|c|c|c|c|c|}
\hline \multirow{2}{*}{ Continent } & \multirow[b]{2}{*}{ Country } & \multicolumn{2}{|c|}{ Prevalence } & \multirow[b]{2}{*}{ References } \\
\hline & & $\begin{array}{c}\text { Serologic assay } \\
(\%)\end{array}$ & $\begin{array}{c}\text { Molecular assay } \\
(\%)\end{array}$ & \\
\hline \multirow{13}{*}{ ASIA } & Jordan & N.A. & 9.8 & Odeh et al., 2010 \\
\hline & Kuwait & N.A. & 24.6 & Odeh et al., 2010 \\
\hline & \multirow{3}{*}{ Saudi Arabia } & 4.3 & N.A. & Alhetheel et al., 2014 \\
\hline & & N.A. & 1 & Mitwalli et al., 2000 \\
\hline & & N.A. & 2 & Al-Ahdal et al., 2000 \\
\hline & South Korea & N.A. & 1.8 & Jeon et al., 2003 \\
\hline & Qatar & N.A. & 13.7 & AbuOdeh et al., 2015 \\
\hline & Thailand & N.A. & 0 & Barusruk et al., 2006 \\
\hline & \multirow{2}{*}{ Taiwan } & N.A. & 2.1 & Wang et al., 1998 \\
\hline & & 10.2 & 3.4 & Yang et al., 2006 \\
\hline & Turkey & N.A. & 0 & Kalkan et al., 2005 \\
\hline & $\begin{array}{l}\text { United Arab } \\
\text { Emirates }\end{array}$ & N.A. & 11.1 & Abu Odeh et al., 2005 \\
\hline & Vietnam & N.A. & 7.4 & Brown et al., 1997 \\
\hline \multirow{31}{*}{ EUROPE } & & 9.5 & 3.4 & Mercier et al., 1999 \\
\hline & France & $\begin{array}{c}14.5 \\
\text { estimated }\end{array}$ & 2.59 & Cantaloube et al., 1999 \\
\hline & \multirow{8}{*}{ Germany } & N.A. & 1.9 & Feucht et al., 1997 \\
\hline & & N.A. & 1.34 & Roth et al., 1997 \\
\hline & & & total donors & \\
\hline & & & 2.18 & \\
\hline & & & $\begin{array}{l}\text { urban donors } \\
0.78\end{array}$ & \\
\hline & & & rural donors & \\
\hline & & N.A. & 2 & Stark et al., 1996 \\
\hline & & N.A. & $\begin{array}{l}1.6 \\
\text { blood donations }\end{array}$ & Hitzler et al., 2004 \\
\hline & Greece & N.A. & $\begin{array}{c}10 \\
\text { healthy individuals }\end{array}$ & Anastassopoulou et al., 2000 \\
\hline & \multirow[b]{2}{*}{ Hungary } & 28 & 8 & Takács et al., 2002 \\
\hline & & $\begin{array}{l}\text { healthy individuals } \\
\text { older than } 60 \text { years }\end{array}$ & healthy individuals & \\
\hline & Iceland & 13.2 & 3.8 & Löve et al., 1999 \\
\hline & \multirow{3}{*}{ Italy } & N.A. & 3.7 & Romanò et al., 2000 \\
\hline & & 12.6 & N.A. & Villari et al., 2001 \\
\hline & & N.A. & 1.5 & Prati et al., 1997 \\
\hline & Norway & 10.5 & 2.5 & Nordbø et al., 2000 \\
\hline & \multirow{2}{*}{ Poland } & 24.2 & 3.2 & Brojer et al., 1999 \\
\hline & & 23.6 & 3.2 & Grabarczyk et al., 2006 \\
\hline & \multirow{2}{*}{ Spain } & N.A. & 3 & Forns et al., 1997 \\
\hline & & 16 & N.A. & Tacke et al., 1997 \\
\hline & \multirow{7}{*}{ Sweden } & 34 & 22 & Shev et al., 1998 \\
\hline & & $\begin{array}{l}\text { HCV infected deferred } \\
\text { blood donors }\end{array}$ & $\begin{array}{l}\text { HCV infected deferred } \\
\text { blood donors }\end{array}$ & \\
\hline & & N.A. & $\begin{array}{c}3.3 \\
\text { all donors }\end{array}$ & Björkman et al., 1998 \\
\hline & & & 1.6 & \\
\hline & & & normal ALT & \\
\hline & & & $\begin{array}{l}4.1 \\
\text { raised ALT }\end{array}$ & \\
\hline & & N.A. & $\begin{array}{c}3 \\
\text { healthy swedish volunteers }\end{array}$ & Lara et al., 1998 \\
\hline & \multirow{2}{*}{ United Kingdom } & N.A. & 1 & Minton et al., 1998 \\
\hline & & N.A. & 2.25 & Blair et al., 1998 \\
\hline
\end{tabular}


Table 1 (continued)

\begin{tabular}{|c|c|c|c|c|}
\hline \multirow[b]{2}{*}{ Continent } & \multirow[b]{2}{*}{ Country } & \multicolumn{2}{|c|}{ Prevalence } & \multirow[b]{2}{*}{ References } \\
\hline & & $\begin{array}{c}\text { Serologic assay } \\
(\%)\end{array}$ & $\begin{array}{c}\text { Molecular assay } \\
(\%)\end{array}$ & \\
\hline \multirow[t]{2}{*}{ OCEANIA } & \multirow[t]{2}{*}{ Australia } & N.A. & $\begin{array}{c}4 \\
\text { normal ALT } \\
5 \\
\text { raised ALT }\end{array}$ & Moaven et al., 1996 \\
\hline & & 10.8 & 2.6 & Hyland et al., 1998 \\
\hline $\begin{array}{l}\text { VARIOUS } \\
\text { COUNTRIES }\end{array}$ & & $\begin{array}{c}\text { Austria } 15.3 \\
\text { Germany } 10.9 \\
\text { Moldova } 13.6 \\
\text { Spain } 12.9 \\
\text { South Africa } 20.3 \\
\text { Brazil } 19.5 \\
\text { Bhutan } 3.9 \\
\text { Malaysia } 6.3 \\
\text { Philippines } 2.7\end{array}$ & N.A. & Ross et al., 1998 \\
\hline
\end{tabular}

N.A. = not applicable; $\mathrm{HCV}=$ hepatitis C virus; IgG = immunoglobulin G; IgM = immunoglobulin M; ALT = alanine aminotransferase.

a scenario that has probably changed, especially in the last $10-15$ years.

\section{Discussion}

Although the discovery of $\mathrm{HPgV}$ goes back about 20 years, several lines of evidence suggest that it is an ancient virus that is well-adapted to growth in the human host. The capacity of adaptation and evolution of $\mathrm{HPgV}$ in humans (common in RNA viruses) seems to be confirmed by the geographical distribution of HPgV genotypes (Sharp et al., 2011). Moreover, the low pathogenicity, the absence of a causal association with human diseases, or the slower progression of the infection could suggest that $\mathrm{HPgV}$ is a human symbiont or commensal (Kapoor et al., 2015) These findings, related to better survival outcomes in HIV-infected individuals led to $\mathrm{HPgV}$ being nicknamed "Good Boy Virus" (Bhattarai and Stapleton, 2012). Moreover, respect to the past, recent epidemiological data provided by several studies report a lower frequency of $\mathrm{HPgV}$ infection markers in haemophilia patients treated with virucidally activated substances rather than non-inactivated blood products (Yamada-Osaki et al., 1998; Kreuz et al., 2002; Grabarczyk et al., 2006). In fact, although the presence of viral RNA in plasma pools and in intravenous immunoglobulins have been shown, currently produced plasma-derived medicinal products are subject to effective inactivation and/or removal steps for viruses such as HPgV (Zhang et al., 2016).

On the other hand, as it appears HPgV anti-inflammatory effects are favourable in selected subjects; its effects on the host immune system function could contribute to the ob- served association between HPgV and non-Hodgkin's lymphoma by reducing immune surveillance mechanisms (Chivero and Stapleton, 2015). An enigmatic aspect, which still requires further clarification, is the mechanisms by which $\mathrm{HPgV}$ infects different blood cell types and persists in humans. A better comprehension of the mechanisms of $\mathrm{HPgV}$ persistence and clearance in humans should be subject of further research. Considering that human pegiviruses are phylogenetically a close relative of HCV, GBV-B has been used as a surrogate model for $\mathrm{HCV}$ infection to understand pathogenesis, immunology, and the $\mathrm{HCV}$ persistence in humans as well as it has been used for the improvement of future development of novel vaccines and immunotherapies (Manickam and Reeves, 2014).

\section{Conclusions}

Due to the lack of studies on pathogenicity of $\mathrm{HPgV}$, its unclear association with known acute disease and the preventive measures already recommended in order to guarantee the safety of blood and blood products, the World Health Organization (WHO), the European Directorate for the Quality of Medicines \& HealthCare (EDQM), and the US Food and Drug Administration (FDA) have not developed recommendations about the risk of transfusion transmissible $\mathrm{HPgV}$ infection. As consequence, currently no country has made a decision to implement $\mathrm{HPgV}$ screening programmes in blood donors; this would seem to be the right decision considering that further studies are necessary to establish the real $\mathrm{HPgV}$ influence on human health as well as on transfusion medicine. Furthermore, as there is no action 
justified at the moment in terms of blood safety a system should be implemented by the competent authorities to monitor further developments in this field. A continuous surveillance of this type seems more reasonable if we take into account that it is very likely, given the rapid progress in viral detection methods, that many other such 'orphan' viruses will be identified, also taking into account the recent discovery of new blood-borne viruses (Kapoor et al., 2015; Berg et al., 2015).

\section{References}

Abu Odeh RO, Al-Absi ES, Ali NH, Hadwan TA, Khalili M, Al-Mawlawi N, Al-Thani AA, Nasrallah GK (2015): Detection and phylogenetic analysis of human pegivirus (GBV-C) among blood donors and patients infected with hepatitis B virus (HBV) in Qatar. J. Med. Virol. 87, 20742081. https://doi.org/10.1002/jmv.24289

Abu Odeh RO, Al-Moslih MI, Al-Jokhdar MW, Ezzeddine SA (2005): Detection and genotyping of GBV-C virus in the United Arab Emirates. J. Med. Virol. 76, 534-540. https:// doi.org/10.1002/jmv.20394

Al-Ahdal MN, Rezeig MA, Kessie G, Chaudhry F, Al-Shammary FJ (2000): $G B$ virus C/hepatitis G virus infection in Saudi Arabian blood donors and patients with cryptogenic hepatitis. Arch Virol 145, 73-84. https://doi.org/10.1007/ s007050050006

Alhetheel A, El-Hazmi MM (2014): Hepatitis G virus in Saudi blood donors and chronic hepatitis B and $\mathrm{C}$ patients. J. Infect. Dev. Ctries. 8, 110-115. https://doi.org/10.3855/ jidc. 3796

Amini S, Andalibi Mahmoodabadi S, Lamian S, Jou-laie M, Mahmoodi Farahani M (2005): Prevalence of hepatitis G virus (HGV) in high-risk groups and blood donors in Tehran, Iran. Iranian J. Publ. Health. 34, 41-46.

Anastassopoulou CG, Delladetsima JK, Anagnostopoulos G, Katsoulidou A, Papachristopoulos A, Tassopoulos NC, Theodoridou M, Hatzakis A (2002): Fulminant hepatic failure in a pediatric patient with active GB virus C (GBV-C)/hepatitis G virus (HGV) infection. Hepatol. Res. 23, 85-89. https://doi.org/10.1016/S1386-6346(01)00166-8

Anastassopoulou CG, Paraskevis D, Tassopoulos NC, Boletis J, Sypsa VA, Hess G, Hatzakis A (2000): Molecular epidemiology of $\mathrm{GB}$ virus $\mathrm{C} /$ hepatitis $\mathrm{G}$ virus in Athens, Greece. J. Med. Virol. 61, 319-326. https://doi.org/10.1002/10969071(200007)61:3<319::AID-JMV6>3.0.CO;2-R

Arankalle VA, Deshmukh TM, Chobe LP, Chadha MS, Walimbe AM (2001): Hepatitis G virus infection in India: prevalence and phylogenetic analysis based as $5^{\prime}$ non coding region. Indian J. Gastroenterol. 20, 13-17.

Barusruk S, Urwijitaroon Y (2006): High prevalence of HGV coinfection with HBV or HCV among northeastern Thai blood donors. Southeast Asian J. Trop. Med. Public Health. 37, 289-293.
Bassit L, Kleter B, Ribeiro-dos-Santos G, Maertens G, Sabino E, Chamone D, Quint W, Sáez-Alquézar A (1998): Hepatitis $G$ virus: prevalence and sequence analysis in blood donors of São Paulo, Brazil. Vox Sang. 74, 83-87. https:// doi.org/10.1159/000030910

Berg MG, Lee D, Coller K, Frankel M, Aronsohn A, Cheng K, Forberg K, Marcinkus M, Naccache SN, Dawson G, Brennan C, Jensen DM, Hackett J Jr, Chiu CY (2015): Discovery of a Novel Human Pegivirus in Blood Associated with Hepatitis C Virus Co-Infection. PLoS pathogens 11, e1005325. https://doi.org/10.1371/journal.ppat.1005325

Bhattarai N, Stapleton JT (2012): GB virus C: the good boy virus? Trends Microbiol. 20, 124-130. https://doi.org/10.1016/j. tim.2012.01.004

Björkman P, Sundström G, Widell A (1998): Hepatitis C virus and GB virus C/hepatitis $G$ virus viremia in Swedish blood donors with different alanine aminotransferase levels. Transfusion 38, 378-384. https://doi.org/10.1046/j.15372995.1998.38498257377.x

Blair CS, Davidson F, Lycett C, McDonald DM, Haydon GH, Yap PL, Hayes PC, Simmonds P, Gillon J (1998): Prevalence, Incidence, and Clinical Characteristics of Hepatitis G Virus/ GB Virus C Infection in Scottish Blood Donors. J. Infect. Dis. 178, 1779-1782. https://doi.org/10.1086/314508

Brojer E, Grabarczyk P, Kryczka W, Kucharski W, Kubicka J, Zupánska B (1999): Analysis of hepatitis G virus infection markers in blood donors and patients with hepatitis. J. Viral Hepat. 6, 471-475. https://doi.org/10.1046/j.13652893.1999.00159.x

Brown KE, Wong S, Buu M, Binh TV, Be TV, Young NS (1997): High prevalence of $G B$ virus $C$ /hepatitis $G$ virus in healthy persons in Ho Chi Minh City, Vietnam J. Infect. Dis. 175, 450-453. https://doi.org/10.1093/infdis/175.2.450

Cantaloube JF, Gallian P, Biagini P, Attoui H, Escher J, Zappitelli JP, Delord Y, de Micco P, de Lamballerie X (1999): Prevalence of $\mathrm{GB}$ virus type $\mathrm{C} /$ hepatitis $\mathrm{G}$ virus RNA and anti-E2 among blood donors in Southeastern France. Transfusion 39, 95-102. https://doi.org/10.1046/j.1537-2995 1999.39199116900.x

Casteling A, Song E, Sim J, Blaauw D, Heyns A, Schweizer R, Margolius L, Kuun E, Field S, Schoub B, Vardas E (1998): GB virus $C$ prevalence in blood donors and high risk groups for parenteraly transmitted agents from Gauteng, South Africa. Med. Virol. 55, 103-108. https://doi. org/10.1002/(SICI)1096-9071(199806)55:2<103::AIDIMV4>3.0.CO;2-6

Chivero ET, Bhattarai N, Rydze RT, Winters MA, Holodniy M, Stapleton JT (2014): Human pegivirus RNA is found in multiple blood mononuclear cells in vivo and serum-derived viral RNA-containing particles are infectious in vitro. J. Gen. Virol. 95, 1307-1319. https://doi.org/10.1099/ vir.0.063016-0

Chivero ET, Stapleton JT (2015): Tropism of human pegivirus (formerly known as GB virus C/hepatitis G virus) and host immunomodulation: insights into a highly successful viral infection. J. Gen. Virol. 96, 1521-1532. https://doi. org/10.1099/vir.0.000086 
Darwish MA, Amer AF, El-Moeity AA, Darwish NM (1998): Hepatitis $G$ virus in Egyptians infected with other parenterally transmitted hepatitis viruses. J. Egypt Public Health Assoc. $73,151-164$.

Deinhardt F, Holmes AW, Capps RB, Popper H (1967): Studies on the transmission of human viral hepatitis to marmoset monkeys. I. Transmission of disease, serial passages, and description of liver lesions. J. Exp. Med. 125, 673-688. https://doi.org/10.1084/jem.125.4.673

Desai MM, Pal RB, Banker DD (2004): GB virus C/hepatitis G virus infection in Indian blood donors and high-risk groups. Transfus. Apher. Sci. 30, 111-117. https://doi. org/10.1016/j.transci.2003.10.006

Deshpande AS, Pathare AD (2013): HGV-HCV/HBV co-infection in India: A pilot study. Asian J. Transfus. Sci. 7, 48-50. https://doi.org/10.4103/0973-6247.106734

El-Zayadi AR, Abe K, Selim O, Naito H, Hess G, Ahdy A (1999): Prevalence of GBV-C/hepatitis $\mathrm{G}$ virus viraemia among blood donors, health care personnel, chronic non-B non-C hepatitis, chronic hepatitis $\mathrm{C}$ and hemodialysis patients in Egypt. J. Virol. Methods 80, 53-58. https://doi. org/10.1016/S0166-0934(99)00036-1

Epstein JH, Quan PL, Briese T, Street C, Jabado O, Conlan S, Ali Khan S, Verdugo D, Hossain MJ, Hutchison SK, Egholm M, Luby SP, Daszak P, Lipkin WI (2010): Identification of GBV-D, a novel GB-like flavivirus from old world frugivorous bats (Pteropus giganteus) in Bangladesh. PLoS Pathog. 6, e1000972. https://doi.org/10.1371/journal. ppat.1000972

Feucht HH, Zöllner B, Polywka S, Knödler B, Schröter M, Nolte H, Laufs R (1997): Prevalence of hepatitis G viremia among healthy subjects, individuals with liver disease, and persons at risk for parenteral transmission. J. Clin. Microbiol. 35, 767-768.

Forns X, Fernández-Llama P, Costa J, López-Labrador FX, Ampurdanés S, Olmedo E, Saiz JC, Guilera M, López-Pedret J, Sánchez-Tapias JM, Darnell A, Jimenez de Anta MT, Ordinas A, Rodés J (1997): Hepatitis G virus infection in a hemodialysis unit: prevalence and clinical implications. Nephrol. Dial. Transplant. 12, 956-960. https://doi. org/10.1093/ndt/12.5.956

Giulivi A, Slinger R, Tepper M, Sher G, Scalia V, Kessler G, Gill P (2000): Prevalence of GBV-C/hepatitis G virus viremia and anti-E2 in Canadian blood donors. Vox Sang. 79, 201-205. https://doi.org/10.1046/j.1423-0410 $.2000 .7940201 . x$

Goubau P, Andrade FB, Liu HF, Basilio FP, Croonen L, BarretoGomes VA (1999): Prevalence of GB virus C/hepatitis G virus among blood donors in north-eastern Brazil. Trop. Med. Int. Health 4, 365-367. https://doi.org/10.1046/ j.1365-3156.1999.00407.x

Grabarczyk P, Brojer E, Windyga J, łopaciuk S, Klukowska A, Mikulska M (2006): GBV-C/HGV and TTV infection markers in Polish blood donors and haemophilia patients. Przegl. Epidemiol. 60, 581-588.

Grassi M, Raffa S, Traditi F, Ferrazzi M, Cioschi S, Fontana M, Pezzella M (2000): Detection and clinical evaluation of
GBV-C/HGV in plasma from patients with chronic hepatitis of unknown etiology. Clin. Ter. 151, 241-245.

Guilera M, Saiz JC, López-Labrador FX, Olmedo E, Ampurdanés S, Forns X, Bruix J, Parés A, Sánchez-Tapias JM, Jiménez de Anta MT, Rodés J (1998): Hepatitis G virus infection in chronic liver disease. Gut 42, 107-111. https://doi. org/10.1136/gut.42.1.107

Haydon GH, Jarvis LM, Simpson KJ, Hayes PC, Simmonds P (1997): The clinical significance of the detection of hepatitis GBV-C RNA in the serum of patients with fulminant, presumed viral, hepatitis. J. Viral Hepat. 4, 45-49. https:// doi.org/10.1046/j.1365-2893.1997.00122.x

Heringlake S, Osterkamp S, Trautwein C, Tillmann HL, Böker K, Muerhoff S, Mushahwar IK, Hunsmann G, Manns MP (1996): Association between fulminant hepatic failure and a strain of GBV virus C. The Lancet 348, 1626-1629. https://doi.org/10.1016/S0140-6736(96)04413-3

Hitzler WE, Runkel S (2004): Prevalence, persistence and liver enzyme levels of HGV RNA-positive blood donors determined by large-scale screening and transmission by blood components. Clin. Lab. 50, 25-31.

Hollingsworth RC, Minton EJ, Fraser-Moodie C, Metivier E, Rizzi PM, Irving WL, Jenkins D, Ryder SD (1998): Hepatitis $\mathrm{G}$ infection: role in cryptogenic chronic liver disease and primary liver cell cancer in the UK. Trent Hepatitis C virus Study Group. J. Viral. Hepat. 5, 165-169. https:// doi.org/10.1046/j.1365-2893.1998.00102.x

Hyland CA, Mison L, Solomon N, Cockerill J, Wang L, Hunt J, Selvey LA, Faoagali J, Cooksley WG, Young IF, Trowbridge R, Borthwick I, Gowans EJ (1998): Exposure to GB virus type $C$ or hepatitis $\mathrm{G}$ virus in selected Australian adult and children populations. Transfusion 38, 821-827. https:// doi.org/10.1046/j.1537-2995.1998.38998409001.x

Iles JC, Abby Harrison GL, Lyons S, Djoko CF, Tamoufe U, Lebreton M, Schneider BS, Fair JN, Tshala FM, Kayembe PK, Muyembe JJ, Edidi-Basepeo S, Wolfe ND, Klenerman P, Simmonds P, Pybus OG (2013): Hepatitis C virus infections in the Democratic Republic of Congo exhibit a cohort effect. Infect. Genet. Evol. 19, 386-394. https:// doi.org/10.1016/j.meegid.2013.01.021

Jain A, Kar P, Gopalkrishna V, Gangwal P, Katiyar S, Das BC (1999): Hepatitis G virus (HGV) infection and pathogenic significance in patients of cirrhosis. Indian J. Med. Res. $110,37-42$.

Jeon MJ, Shin JH, Suh SP, Lim YC, Ryang DW (2003): TT virus and HGV infection in Korean blood donors and patients with chronic liver disease. World J. Gastroenterol. 94, 741-747. https://doi.org/10.3748/wjg.v9.i4.741

Kalkan A, Ozdarendeli A, Bulut Y, Saral Y, Ozden M, Keleștimur N, Toraman ZA (2005): Prevalence and genotyping distribution of hepatitis GB-C/HG and TT viruses in blood donors, mentally retarded children and four groups of patients in Eastern Anatolia Turkey. Jpn. J. Dis. 58, 222-227.

Kanda T, Yokosuka O, Ehata T, Maru Y, Imazeki F, Saisho H, Shiratori Y, Omata M (1996): GBV-C is unlikely to be the cause of non-A-E fulminant hepatitis in Japan. Hepatology $24,531 \mathrm{~A}$. 
Kapoor A, , Kumar A, Simmonds P, Bhuva N, Singh Chauhan L, Lee B, Sall AA, Jin Z, Morse SS, Shaz B, Burbelo PD, Lipkin WI (2015): Virome Analysis of Transfusion Recipients Reveals a Novel Human Virus That Shares Genomic Features with Hepaciviruses and Pegiviruses. MBio. 6, e01466-15. https://doi.org/10.1128/mBio.01466-15

Kapoor S, Gupta RK, Das BC, Kar P (2000): Clinical implications of hepatitis $\mathrm{G}$ virus (HGV) infection in patients of acute viral hepatitis \& fulminant hepatic failure. Indian J. Med. Res. 112, 121-127.

Kar P, Bedi P, Berry N, Chakravorty A, Gupta RK, Saha R, Das BC (2000): Hepatitis G virus (HGV) infection in voluntary and commercial blood donors in India. Diagn. Microbiol. Infect. Dis. 38, 7-10. https://doi.org/10.1016/S0732-8893(00)00168-1

Kreuz W, Becker S, Auerswald G, Kurnick K, Kröniger A, Klarmann D (2002): Virus safety of pasteurized clotting factor concentrates. Semin. Thromb. Hemost. 28, 57-62. https://doi. org/10.1055/s-2002-30197

Kumar D, Gupta RK, Anand R, Pasha ST, Rai A, Das BC, Kar $P$ (2007): Occurrence \& nucleotide sequence analysis of hepatitis $G$ virus in patients with acute viral hepatitis \& fulminant hepatitis. Indian J. Med. Res. 125, 752-755.

Lampe E, de Oliveira JM, Pereira JL, Saback FL, Yoshida CF, Niel C (1998): Hepatitis G virus (GBV-C) infection among Brazilian patients with chronic liver disease and blood donors. Clin. Diagn. Virol. 9, 1-7.

Lanteri MC, Tan S, Stapleton JT, Norris PJ, Heitman J, Deng X, Keating SM, Brambilla D, Busch MP, Custer B, NHLBI REDS III Study (2015): Downregulation of Cytokines and Chemokines by GB Virus C After Transmission Via Blood Transfusion in HIV-Positive Blood Recipients. J. Infect. Dis. 211, 1585-1596. https://doi.org/10.1093/ infdis/jiu660

Lara C, Halasz R, Sönnerborg A, Sällberg M (1998): Detection of hepatitis $G$ virus RNA in persons with and without known risk factors for blood-borne viral infections in Sweden and Honduras. J. Clin. Microbiol. 36, 255-257.

Lauck M, Bailey AL, Andersen KG, Goldberg TL, Sabeti PC, O'Connor DH (2015): GB virus C coinfections in west African Ebola patients. J. Virol. 89, 2425-2429. https:// doi.org/10.1128/JVI.02752-14

Lefrère J-J, Loiseau P, Maury J, Lasserre J, Mariotti M, Ravera N, Lerable J, Lefèvre G, Morand-Joubert L, Girot R (1997): Natural History of GBV-C/Hepatitis G Virus Infection Through the Follow-Up of GBV-C/Hepatitis G VirusInfected Blood Donors and Recipients Studied by RNA Polymerase Chain Reaction and Anti-E2 Serology. Blood 90, 3776-3780.

Levi JE, Contri DG, Lima LP, Takaoka DT, Garrini RH, Santos W, Fachini R, Wendel S (2003): High prevalence of GB virus C/hepatitis G virus RNA among Brazilian blood donors. Rev. Inst. Med. Trop. Sao Paulo 45, 75-78.

Li G, Ma HH, Lau GK, Leung YK, Yao CL, Chong YT, Tang WH, Yao JL (2002): Prevalence of hepatitis G virus infection and homology of different viral strains in Southern China. World J. Gastroenterol. 8, 1081-1087.
Linnen J, Wages J Jr, Zhang-Keck ZY, Fry KE, Krawczynski KZ, Alter H, Koonin E, Gallagher M, Alter M, Hadziyannis S, Karayiannis P, Fung K, Nakatsuji Y, Shih JW, Young L, Piatak M Jr, Hoover C, Fernandez J, Chen S, Zou JC, Morris T, Hyams KC, Ismay S, Lifson JD, Hess G, Foung SK, Thomas H, Bradley D, Margolis H, Kim JP (1996): Molecular cloning and disease association of hepatitis $\mathrm{G}$ virus: a transfusion-transmissible agent. Science 271, 505508. https://doi.org/10.1126/science.271.5248.505

López-Izquierdo R, Udaondo MA, Zarzosa P, García-Ramón E, Garcinuño S, Bratos MA, Orduña A, Rodríguez-Torres A, Almaraz A (2007): Seroprevalence of viral hepatitis in a representative general population of an urban public health area in Castilla y León (Spain). Enferm. Infecc. Microbiol. Clin. 25, 317-323.

Löve A, Stanzeit B, Gudmundsson S, Widell A (1999): Hepatitis $\mathrm{G}$ virus infections in Iceland. J. Viral Hepat. 6, 255-260. https://doi.org/10.1046/j.1365-2893.1999.00143.x

Lyra AC, Pinho JR, Silva LK, Sousa L, Saraceni CP, Braga EL, Pereira JE, Zarife MA, Reis MG, Lyra LG, Silva LC, Carrilho FJ. (2005): HEV, TTV and GBV-C/HGV markers in patients with acute viral hepatitis. Braz. J. Med. Biol. Res. 38, 767-775.

Manickam C, Reeves RK (2014): Modeling HCV disease in animals: virology, immunology and pathogenesis of $\mathrm{HCV}$ and GBV-B infections. Front. Microbiol. 5, 690.

Mastouri M, Safer IL, Pozzetto B, Bourlet T, Khedher M (2005): Prevalence of hepatitis $G$ virus among Tunisian blood donors. East Mediterr. Health J. 11, 1053-1060.

Mercier B, Barclais A, Botte C, Cantalube J, Coste J, Defer C, Gautreau C, Giannoli C, Halfon P, Lepot I, Loiseau P, Martial J, Montcharmont P, Merel P, Ouzan D, Ravera N, Follana J, Césaire R, Janot C, Lemaire J, De Micco P, Vezon G, Férec C (1999): Prevalence of GBV C/HGV RNA and GBV C/ HGV antibodies in French volunteer blood donors: results of a collaborative study. Vox Sang. 76, 166-169. https:// doi.org/10.1046/j.1423-0410.1999.7630166.x

Minton J, Iqbal A, Eskiturk A, Irving W, Davies J (1998): Hepatitis $\mathrm{G}$ virus infection in lymphoma and in blood donors. J. Clin. Pathol. 51, 676-678.

Mitwalli AH, Al Wakeel JS, Alam AA, Nauman T, Al Rashed RS, Ramia S (2000): Hepatitis G virus (HGV) infection in Saudi dialysis patients and healthy controls. Saudi J. Gastroenterol. 6, 79-83.

Moaven LD, Hyland CA, Young IF, Bowden DS, McCaw R, Mison L, Locarnini SA (1996): Prevalence of hepatitis G virus in Queensland blood donors. Med. J. Aust. 165, 369-371.

Mohr EL, Stapleton JT (2009): GB virus type C interactions with HIV: the role of envelope glycoproteins. J. Viral Hepat. 16, 757-768. https://doi.org/10.1111/j.1365-2893 $.2009 .01194 . \mathrm{x}$

Noguchi S, Sata M, Suzuki H, Ohba K, Mizokami M, Tanikawa K (1997): GB virus C (GBV-C)/hepatitis G virus (HGV) infection among intravenous drug users in Japan. Virus Res. 49, 155-162. https://doi.org/10.1016/S0168-1702(97)01470-6

Nordbø SA, Krokstad S, Winge P, Skjeldestad FE, Dalen AB (2000): Prevalence of GB virus C (also called hepatitis G virus) 
markers in Norwegian blood donors. J. Clin. Microbiol. 38, 2584-2590.

Odeh RA, Yasin S, Nasrallah G, Babi Y (2010): Rates of infection and phylogenetic analysis of GB virus- $C$ among Kuwaiti and Jordanian blood donors. Intervirol. 53, 402-407. https://doi.org/10.1159/000317290

Oliveira LA, Martins RM, Carneiro MA, Teles SA, Silva SA, Cardoso DD, Lampe E, Yoshida CF (2002): Prevalence and genotypes of $\mathrm{GB}$ virus $\mathrm{C} /$ hepatitis $\mathrm{G}$ virus among blood donors in Central Brazil Mem. Inst. Oswaldo Cruz 97, 953-957. https://doi.org/10.1590/S0074-02762002000700005

Omar M, Fam N, Saad El-Dine S (2006) Impact of Hepatitis G Virus Infection on Chronic Hepatitis C Egyptian Patients: Clinical, Virological and Ultrastructural Aspects. Life Sci. J. 3, 9-17.

Orito E, Mizokami M, Nakano T, Wu RR, Cao K, Ohba K, Ueda R, Mukaide M, Hikiji K, Matsumoto Y, Iino S (1996): $\mathrm{GB}$ virus $\mathrm{C} /$ hepatitis $\mathrm{G}$ virus infection among Japanese patients with chronic liver diseases and blood donors. Virus Res. 46, 89-93. https://doi.org/10.1016/S01681702(96)01379-2

Pessoa MG, Terrault NA, Detmer J, Kolberg J, Collins M, Hassoba HM, Wright TL (1998): Quantitation of hepatitis G and $\mathrm{C}$ viruses in the liver: evidence that hepatitis $\mathrm{G}$ virus is not hepatotropic. Hepatol. 27, 877-880. https://doi. org/10.1002/hep. 510270335

Praharaj AK, Tripathy S, Kalghatgi AK, Nagendra A (2005): Hepatitis $\mathrm{G}$ virus: Prevalence in blood donors in armed forces. MJAFI 61, 333-335. https://doi.org/10.1016/S0377-1237(05)80057-7

Prati D, Capelli C, Zanella A, Bosoni P, De Mattei C, Mozzi F, Donato MF, Colombo M, Milani S, Sirchia G (1997): Asymptomatic hepatitis $\mathrm{G}$ virus infection in blood donors. Transfusion 37, 1200-1204. https://doi.org/10.1046/ j.1537-2995.1997.37111298088052.x

Ramezani A, Gachkar L, Eslamifar A, Khoshbaten M, Jalilvand S, Adibi L, Salimi V, Hamkar R (2008): Detection of hepatitis $\mathrm{G}$ virus envelope protein $\mathrm{E} 2$ antibody in blood donors. Int. Infect. Dis. 12, 57-61.

Ren FR, Wang Y, Li H, Chen HS, Zhao HY (1998): Hepatitis G virus infection in screened Chinese blood donors. Vox Sang. 74, 51-52. https://doi.org/10.1046/j.1423-0410 $.1998 .7410051 . \mathrm{x}$

Rezvan H, Sharafi M, Shams H, Mahmoodian Shoos-htari M (2007): A preliminary report on prevalence of antibody response to GBV-C, E2 protein in Iranian blood donors and multi trans fused patients. Iranian J. Publ. Health. 36, 6-11.

Romanò L, Fabris P, Tanzi E, Tositti G, Mazzotta F, Zanetti AR (2000): GBV-C/hepatitis G virus in acute nonA-E hepatitis and in acute hepatitis of defined aetiology in Italy. J. Med. Virol. 61, 59-64. https://doi.org/10.1002/(SICI)10969071(200005)61:1<59::AID-JMV9>3.0.CO;2-Y

Ross RS, Viazov S, Schmitt U, Schmolke S, Tacke M, OfenlochHaehnle B, Holtmann M, Müller N, Da Villa G, Yoshida CF, Oliveira JM, Szabo A, Paladi N, Kruppenbacher JP, Philipp T, Roggendorf M (1998): Distinct prevalence of antibodies to the $\mathrm{E} 2$ protein of $\mathrm{GB}$ virus $\mathrm{C} /$ hepatitis
$\mathrm{G}$ virus in different parts of the world. J. Med. Virol. 54, 103-106. https://doi.org/10.1002/(SICI)1096-9071(199802)54:2<103::AID-JMV6>3.0.CO;2-A

Roth WK, Waschk D, Marx S, Tschauder S, Zeuzem S, Bialleck H, Weber H, Seifried E (1997): Prevalence of hepatitis $G$ virus and its strain variant, the GB agent in blood donations and their transmission to recipients. Transfusion 37, 651-656. https://doi.org/10.1046/j.1537-2995 $.1997 .37697335162 . \mathrm{x}$

Saitoh H, Moriyama M, Matsumura H, Goto I, Tanaka N, Aarakawa $\mathrm{Y}$ (2002): The clinical significance of GBV-C/HGV exposure in C-viral chronic liver disease and blood donors. Hepatol. Res. 22, 288-296.

Saiz JC, Sans M, Mas A, Olmedo E, Forns X, López-Labrador FX, Restrepo JC, Costa J, Salmerón JM, Guilera M, Ampurdanés S, Sánchez-Tapias JM, Jiménez de Anta MT, Rodés J (1997): Hepatitis G virus infection in fulminant hepatic failure. Gut 41, 696-699. https://doi.org/10.1136/ gut.41.5.696

Sathar MA, Soni PN, Naicker S, Conradie J, Lockhat F, Gouws E (1999): GB virus C/hepatitis $G$ virus infection in KwaZulu Natal, South Africa. J. Med. Virol. 59, 38-44.

Schaluder GG, Dawson GJ, Simons JN, Pilot-Matias TJ, Gutierrez RA, Heynen CA, Knigge MF, Kurpiewski GS, Buijk SL, Leary TP et al. (1995): Molecular and serologic analysis in the transmission of the GB hepatitis agents. J. Med. Virol. 46, 81-90.

Schwarze-Zander C, Blackard JT, Rockstroh JK (2012): Role of GB virus $\mathrm{C}$ in modulating HIV disease. Expert. Rev. Anti. Infect. Ther. 10, 563-572.

Sharp PM, Simmonds P (2011): Evaluating the evidence for virus/ host co-evolution. Curr. Opin. Virol. 1, 436-441.

Sheng L, Soumillion A, Beckers N, Wu CG, Verslype C, Nevens F, Pirenne J, Aerts R, Kosala H, Fevery J, Yap SH (1998): Hepatitis $G$ virus infection in acute fulminant hepatitis: prevalence of $\mathrm{HGV}$ infection and sequence analysis of a specific viral strain. J. Viral Hepat. 5, 301-306. https:// doi.org/10.1046/j.1365-2893.1998.00123.x

Shev S, Björkman P, Norkrans G, Foberg U, Frydén A, Lindh G, Lindholm A, Weiland O, Widell A (1998): GBV-C/HGV infection in hepatitis $\mathrm{C}$ virus-infected deferred Swedish blood donors. J. Med. Virol. 54, 75-79.

Showkath MS, Chowdhury OA, Das S, Fatema KD, Das KP, Khan MMU (2014): Seroprevalence of Hepatitis G Virus IgG Antibody among Blood Donors, Pregnant Women, Neonates and Apparently Healthy Population. Faridpur Med. Coll. J 9, 28-31.

Simons JN, Leary TP, Dawson GJ, Pilot-Matias TJ, Muerhoff AS, Schlauder GG, Desai SM, Mushahwar IK (1995): Isolation of novel virus-like sequences associated with human hepatitis. Nat. Med. 1, 564-5699.

Stapleton JT, Foung S, Muerhoff AS, Bukh J, Simmonds P (2011): The GB viruses: a review and proposed classification of GBV-A, GBV-C (HGV), and GBV-D in genus Pegivirus within the family Flaviviridae. J. Gen. Virol. 92, 233-246. https://doi.org/10.1099/vir.0.027490-0

Stapleton JT, Xiang J, McLinden JH, Bhattarai N, Chivero ET, Klinzman D, Kaufman TM, Chang Q (2014): A Novel T Cell 
Evasion Mechanism in Persistent RNA Virus Infection. Trans. Am. Clin. Climatol. Assoc. 125, 14-26.

Stark K, Bienzle U, Hess G, Engel AM, Hegenscheid B, Schluter V (1996): Detection of the hepatitis G virus genome among injecting drug users, homosexual and bisexual men, and blood donors. J. Infect. Dis. 174, 1320-1323.

Tacke M, Schmolke S, Schlueter V, Sauleda S, Esteban JI, Tanaka E, Kiyosawa K, Alter HJ, Schmitt U, Hess G, OfenlochHaehnle B, Engel AM (1997): Humoral immune response to the $\mathrm{E} 2$ protein of hepatitis $\mathrm{G}$ virus is associated with long-term recovery from infection and reveals a high frequency of hepatitis $G$ virus exposure among healthy blood donors. Hepatology 26, 1626-1633. https://doi. org/10.1002/hep.510260635

Takács M, Szomor KN, Szendroi A, Dencs A, Brojnás J, Rusvai E, Berencsi G (2002): Prevalence of GB virus C/hepatitis $\mathrm{G}$ virus in Hungary. FEMS Immunol. Med. Microbiol. $34,283-287$.

Tao I, Bisseye C, Nagalo BM, Sanou M, Kiba A, Surat G, Compaoré TR, Traoré L, Nikiema JB, Pietra V, Zongo JD, Simpore J (2013): Screening of Hepatitis G and EpsteinBarr Viruses Among Voluntary non Remunerated Blood Donors (VNRBD) in Burkina Faso, West Africa. Mediterr. J. Hematol. Infect. Dis. 5, e2013053. doi: 10.4084/MJHID.2013.053. eCollection 2013. https://doi. org/10.4084/mjhid.2013.053

Thézé J, Lowes S, Parker J, Pybus OG (2015): Evolutionary and phylogenetic analysis of the hepaciviruses and pegiviruses. Genome Biol. Evol. 7, 2996-3008.

Uygun A, Kadayifci A, Kubar A, Tuzun A, Erdil A, Gulsen M, Bagci S, Karaeren N, Dagalp K (2000): Insignificant role of hepatitis $G$ virus infection in patients with liver enzyme elevations of unknown etiology. J. Clin. Gastroenterol. 31, 73-76.

Vahidnia F, Petersen M, Stapleton JT, Rutherford GW, Busch M, Custer B (2012): Acquisition of GB virus type C and lower mortality in patients with advanced HIV disease. Clin. Infect. Dis. 55, 1012-1019.

Villari P, Ribera G, Nobile CG, Torre I, Ricciardi G (2001): Antibodies to the $\mathrm{E} 2$ protein of $\mathrm{GB}$ virus $\mathrm{C} / \mathrm{h}$ epatitis $\mathrm{G}$ virus: prevalence and risk factors in different populations in Italy. Infection 29, 17-23. https://doi.org/10.1007/s15010-001-0050-0
Wang JT, Chen PJ, Liu DP, Sheu JC, Wang TH, Chen DS (1998): Prevalence and infectivity of hepatitis $G$ virus and its strain variant, the GB agent, in volunteer blood donors in Taiwan. Transfusion 38, 290-295. https://doi.org/10.1046/ j.1537-2995.1998.38398222874.x

Woolhouse M, Scott F, Hudson Z, Howey R, Chase-Topping M (2012): Human viruses: discovery and emergence. Philos. Trans. R. Soc. Lond. B. Biol. Sci. 367, 2864-2871.

Wu RR, Mizokami M, Cao K, Nakano T, Ge XM, Wang SS, Orito E, Ohba K, Mukaide M, Hikiji K, Lau JY, Iino S (1997): $\mathrm{GB}$ virus $\mathrm{C} /$ hepatitis $\mathrm{G}$ virus infection in southern China. J. Infect. Dis. 175, 168-171.

Xiao W, Lin F, Sun P, Ma L, Li C (2014): Detection of GB virus C/ hepatitis $\mathrm{G}$ markers in Chinese voluntary blood donors. Braz. J. Infect. Dis. 18, 352-353

Yamada-Osaki M, Sumazaki R, Kajiwara Y, Miyakawa T, Shirahata A, Matsui A (1998): Natural course of HGV infection in haemophiliacs. Br. J. Haematol. 102, 616-621. https://doi. org/10.1046/j.1365-2141.1998.00793.x

Yan J, Chen LL, Luo YH, Mao YF, He M (2001): High frequencies of HGV and TTV infections in blood donors in Hangzhou. World J. Gastroenterol. 7, 637-641.

Yang JF, Dai CY, Chuang WL, Lin WY, Lin ZY, Chen SC, Hsieh MY, Wang LY, Tsai JF, Chang WY, Yu ML (2006): Prevalence and clinical significance of $\mathrm{HGV} / \mathrm{GBV}-\mathrm{C}$ infection in patients with chronic hepatitis B or C. Jpn. Infect. Dis. 59, 25-30.

Yoshiba M, Dehara K, Inoue K, Okamoto H, Mayumi M (1994): Contribution of hepatitis $\mathrm{C}$ virus to non- $\mathrm{A}$, non-B fulminant hepatitis in Japan. Hepatology 19, 829-835. https:// doi.org/10.1002/hep.1840190405

Yoshikawa A, Fukuda S, Itoh K, Kosaki N, Suzuki T, Hirakawa K, Nakao H, Inoue T, Fukuda M, Okamoto H (1997): Infection with hepatitis $\mathrm{G}$ virus and its strain variant, the GB agent (GBV-C), among blood donors in Japan. Transfusion 37, 657-663. https://doi.org/10.1046/j.15372995.1997.37697335163.x

Zhang W, Li L, Deng X, Blümel J, Nübling CM, Hunfeld A, Baylis SA, Delwart E (2016): Viral nucleic acids in human plasma pools. Transfusion 56, 2248-2255. https://doi. org/10.1111/trf.13692 